\title{
Interferon in rabbit sera after inoculation with Treponema pallidum suspensions contaminated with PED virus
}

\author{
K L FENNESTAD,* L BRUUN,* AND S HAAHR† \\ From the *Animal Department, Statens Seruminstitut, Copenhagen; and the +Institute of Medical \\ Microbiology, Aarhus University, Aarhus, Denmark
}

SUMMARY Paired rabbit sera were examined for the presence of interferon and pathogenicity for rabbits. The sera were obtained before and 48 hours after inoculation with Treponema pallidum suspensions of rabbit origin in 12 selected laboratories.

Classical interferon, detectable in dilutions from $1 / 9$ to $1 / 81$, were found in 27 out of 39 postinoculation sera from which the pleural effusion disease (PED) virus was isolated. Serum interferon was not detectable in dilutions $>1 / 9$ in 16 virus-negative postinoculation sera or in any of the 55 preinoculation sera. Interferon was found more often in sera from which highly virulent strains of PED virus were isolated than in sera from which strains of low virulence were isolated.

The serum interferon assay provides useful presumptive evidence of contamination of rabbitpassaged treponemes with PED virus, but the assay is least useful when PED virus is present subclinically.

\section{Introduction}

Pleural effusion disease (PED) agent or virus occurs as a passenger in Treponema pallidum suspensions of rabbit origin, causing intercurrent infection of rabbits, which may vary from a subclinical to a fatal disease. ${ }^{1-3}$ The virus is poorly characterised and has not been demonstrated convincingly by culture, electron microscopy, or a specific serological technique ${ }^{4-6}$; it has, however, been found to produce circulating interferon. ${ }^{5}$

During a recent survey of laboratories paired sera were obtained before and 48 hours after intratesticular inoculation with $T$ pallidum. These sera were used in a rabbit test for PED virus. By this test the agent was detected in all postinoculation sera from seven laboratories but not in those from five laboratories or in preinoculation sera from all 12 laboratories. ${ }^{3}$

This study reports the results of examining these paired sera for interferon. Furthermore, since the above rabbit test included inoculation of each serum into a rabbit, it was possible to compare the inter-

Address for reprints: Dr K L Fennestad, Animal Department, Statens Seruminstitut, Amager Boulevard 80, DK 2300 Copenhagen S, Denmark

Accepted for publication 23 December 1981 feron titres of the paired sera with the rabbit pathogenicity of the same sera.

\section{Materials and methods}

The paired rabbit sera were received in 1978-79 from selected laboratories (Nos 1-12) and had been stored since then at $-70^{\circ} \mathrm{C}$. The criteria for selection and geographical location of the laboratories, together with details of the sera and the treponemal inocula, have been described. ${ }^{3}$

Four pairs of sera from the material were excluded from the present study: two pairs (laboratory No 11), because the samples were collected 96 hours after inoculation, one pair (laboratory No 2), because the preinoculation sample was lost, and one pair (laboratory No 3), because the preinoculation sample was inadvertently contaminated. Included in the study were an additional five pairs of sera received from laboratory No 5 after it had been informed of the results of the first set of sera. These last sera came from rabbits inoculated with a treponemal suspension from a rabbit testis which had been stored in liquid nitrogen for five years. The inoculum represented the routinely used substrain of Nichols pathogenic $T$ pallidum from an earlier period when laboratory No 5 had a very low intercurrent mortality among inoculated rabbits (personal communication). ${ }^{7}$ The final material therefore comprised 55 paired sera. 
SERUM INTERFERON ASSAY

The sera and tissue culture media were dialysed against Sørensen's buffer pH 2 and after 48 hours at $4^{\circ} \mathrm{C}$ dialysed back to $\mathrm{pH} 7 \cdot 4$. Some of the sera were centrifuged at $110000 \times g$ for three hours at $4^{\circ} \mathrm{C}$.

The culture used was a continuous rabbit kidney cell line (RK13), originally received from Dr Annelise Godtfredsen, Statens Seruminstitut, Copenhagen. The cells were grown in 1-litre Roux flasks, using Eagle's MEM with $15 \%$ calf serum as growth medium and Eagle's MEM with $2 \%$ calf serum as maintenance medium. Both media contained 200 IU penicillin, $0.2 \mathrm{mg}$ streptomycin, and $20 \mathrm{IU}$ mycostatin per $\mathrm{ml}$.

A micromethod was used in which Microtest II (Falcon) wells were seeded with RK13-cells, 30000 cells/well in a volume of $0.1 \mathrm{ml}$. After growth to confluence, serial three-fold dilutions of the sera or tissue culture media to be tested were made directly in the wells. Twenty-four hours later the cells were challenged with vesicular stomatitis virus ( 500 plaqueforming units in $0.1 \mathrm{ml} /$ well) and the cytopathic effect was read microscopically after incubation for 24 hours. The interferon titres represented the dilution that reduced the cytopathic effect by $50 \%$. All samples were tested in duplicate rows. An interferon standard of known titre was included on each plate to correct for fluctuations in the sensitivity of the system.

Control interferon was induced in rabbits weighing 2-3 kg by double-stranded polynucleotide (Poly I/Poly C, Miles Laboratories). The compound was dissolved in PBS ( $\mathrm{pH} \mathrm{7.3)}$ at a concentration of $1000 \mathrm{U} / \mathrm{ml}$. Each rabbit was given $1 \mathrm{ml}$ intravenously. Blood was taken from an ear vein after two hours. The serum was dialysed against Sørensen's buffer $\mathrm{pH} 2$, and after 48 hours at $4^{\circ} \mathrm{C}$ it was dialysed back to $\mathrm{pH} 7 \cdot 4$.

The viral inhibitor found in the dilutions of sera was stable at pH 2 for 48 hours, partly inactivated at $56^{\circ} \mathrm{C}$ for 30 minutes, and inactivated by trypsin. No changes in the viral inhibitory effect was found after centrifugation at $110000 \times g$ for three hours at $4^{\circ} \mathrm{C}$. This indicated type 1 interferon or classical interferon. ${ }^{9}$

PATHOGENICITY TEST

To determine the pathogenicity of each serum for rabbits $0.2 \mathrm{ml}$ serum mixed with $0.8 \mathrm{ml}$ of PBS
(pH 7-0) was given subcutaneously to one rabbit. All $\frac{\mathbb{D}}{\overparen{D}}$ rabbits were albino males, weighing $2-3 \mathrm{~kg}$ from the same closed colony (Ssc:CPH). After inoculation the rabbits were observed for clinical signs of disease for $\vec{\Rightarrow}$ a period of 10 days, particularly those characteristic $\stackrel{\mathscr{\rho}}{\rightarrow}$ of PED. ${ }^{10}$ The clinical response of the individual rabbits was classified according to the severity of the $\overline{\bar{\sigma}}$ disease: A-fatal disease with necropsy findings $\frac{\bar{\rho}}{\frac{}{\sigma}}$ characteristic of PED; B-febrile disease with $\stackrel{\mathbb{Q}}{\Omega}$ iridocyclitis; C-transient fever within three days after inoculation; and D-no clinical signs of disease. A rectal temperature of $40^{\circ} \mathrm{C}$ or higher was con-? sidered as fever, except in one case of $39 \cdot 9^{\circ} \mathrm{C}$.

\section{VIRUS ISOLATION}

The results of isolation of PED virus from the post- in inoculation sera have been reported previously ${ }^{3}$ but $\omega$ are included in this study.

\section{Results}

Tables I and II summarise the results of examining sera obtained before and 48 hours after intratesticular inoculation of rabbits with $T$ pallidum $\vec{c}$ suspensions in the 12 laboratories.

\section{PREINOCULATION SERA}

Neither PED virus nor interferon was detectable in the individual sera before inoculation withoे treponemes (table I). When the same sera were $\frac{\mathrm{D}}{\mathrm{Q}}$ examined for rabbit pathogenicity, four sera (from laboratory Nos 2, 5, and 6) produced transient fever음 ( $C$ response), while the remaining 51 sera failed to induce clinical signs of disease (D response).

\section{POSTINOCULATION SERA}

In the virus-positive group of laboratories the interferon titres varied from $<3$ to 81 (table II). An interferon titre of $\geqslant 3$ was found in 28 out of 39 viruspositive sera. Nevertheless, 11 of the 39 virus-positive

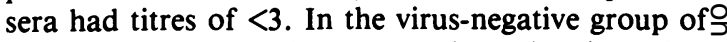
laboratories two of the 16 sera showed a titre of $3, D$ while the rest had a titre of $<3$ (table II). If anㅡ. interferon titre of $\geqslant 9$ is considered specific, that is, $\bar{N}$ caused by PED virus infection, 27 out of the 39 viruspositive sera showed the presence of interferon. At 0 least one serum from each virus-positive laboratory showed a titre of $\geqslant 9$.

TABLE I PED virus isolation, interferon titres, and rabbit pathogenicity in 55 preinoculation sera

\begin{tabular}{|c|c|c|c|c|}
\hline \multirow[b]{2}{*}{ Laboratory No } & \multirow[b]{2}{*}{ No of sera } & \multirow[b]{2}{*}{$P E D$ virus isolated } & \multicolumn{2}{|l|}{ Individual sera } \\
\hline & & & Interferon titre & Pathogenicity* \\
\hline $1-12$ & 55 & 0 & All $<3$ & $4 C, 51 D$ \\
\hline \multicolumn{5}{|l|}{ * See text } \\
\hline
\end{tabular}


TABLE II PED virus isolation, interferon titres, and rabbit pathogenicity in 55 postinoculation sera

\begin{tabular}{|c|c|c|c|}
\hline & & & Individual sera \\
\hline Laboratory No & No of sera & $P E D$ virus isolated & Interferon titre/pathogenicity* \\
\hline $\begin{array}{l}\text { (Virus-positive) } \\
2 \\
3 \\
5 \mathrm{a} \dagger \\
5 \mathrm{~b} \\
6 \\
7 \\
8 \\
12\end{array}$ & $\begin{array}{l}5 \\
3 \\
5 \\
5 \\
8 \\
4 \\
5 \\
4\end{array}$ & $\begin{array}{l}5 \\
3 \\
5 \\
5 \\
8 \\
4 \\
5 \\
4\end{array}$ & $\begin{array}{l}9 / \mathrm{C}, 9 / \mathrm{C}, 81 / \mathrm{B}, 3 / \mathrm{B}, 27 / \mathrm{B} \\
<3 / \mathrm{A}, 27 / \mathrm{C}, 81 / \mathrm{B} \\
27 / \mathrm{A}, 9 / \mathrm{A},<3 / \mathrm{B}, 9 / \mathrm{A},<3 / \mathrm{C} \\
<3 / \mathrm{C},<3 / \mathrm{C},<3 / \mathrm{C}, 9 / \mathrm{D}, 9 / \mathrm{C} \\
27 / \mathrm{C}, 27 / \mathrm{B}, 27 / \mathrm{A}, 81 / \mathrm{A}, 27 / \mathrm{B}, 27 / \mathrm{A}, 27 / \mathrm{B}, 27 / \mathrm{B} \\
81 / \mathrm{C}, 27 / \mathrm{B}, 27 / \mathrm{B}, 27 / \mathrm{B} \\
81 / \mathrm{B},<3 / \mathrm{B}, 27 / \mathrm{C}, 9 / \mathrm{B},<3 / \mathrm{B} \\
<3 / \mathrm{D},<3 / \mathrm{D}, 9 / \mathrm{C},<3 / \mathrm{C}\end{array}$ \\
\hline $\begin{array}{c}\text { (Virus-negative) } \\
1 \\
4 \\
9 \\
10 \\
11\end{array}$ & $\begin{array}{l}4 \\
4 \\
2 \\
4 \\
2\end{array}$ & $\begin{array}{l}0 \\
0 \\
0 \\
0 \\
0\end{array}$ & $\begin{array}{l}\text { 3/D, <3/D, 3/D, <3/D } \\
<3 / \mathrm{D},<3 / \mathrm{D},<3 / \mathrm{D},<3 / \mathrm{D} \\
<3 / \mathrm{D},<3 / \mathrm{D} \\
<3 / \mathrm{D},<3 / \mathrm{D},<3 / \mathrm{D},<3 / \mathrm{D} \\
<3 / \mathrm{D},<3 / \mathrm{C}\end{array}$ \\
\hline
\end{tabular}

* See text

† Laboratory No 5 represented by two sets of sera

The pathogenicity of the postinoculation sera varied in response from $A$ to $D$ in the virus-positive laboratories, whereas $\mathrm{a} C$ or $\mathrm{D}$ response was obtained with sera from the virus-negative laboratories (table II).

In the figure the interferon titres of the 55 postinoculation sera are grouped according to the clinical response after inoculation of rabbits with the sera. The range and mean of interferon titres of the viruspositive sera were the same for the $A$ and $B$ responses, whereas the titres of the virus-positive sera tended to be lower for the $C$ and $D$ responses. If the $A$ and $B$ responses are grouped together and compared with the group of $C$ and $D$ responses there is a significant difference in titres between the two groups $(P<0 \cdot 05$, Wilcoxon's two-sample test). This shows a correlation between interferon production and the severity of the disease.

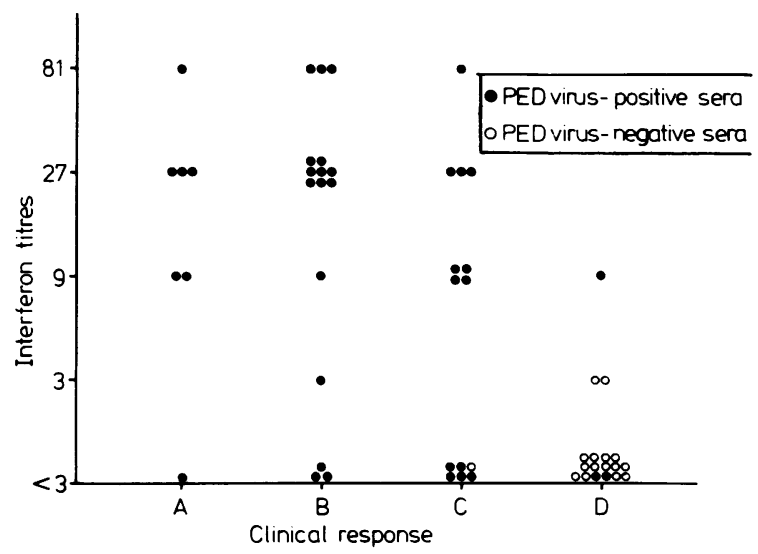

FIGURE Correlation between interferon titres of postinoculation sera and severity of clinical response after rabbit inoculation.

\section{Discussion}

The idea that the presence of interferon in serum may be used as presumptive evidence of acute viral infections was proposed many years ago ${ }^{11}$ and has since been supported by other observations. ${ }^{12} 13$ Recently, Matthews and Lawrence ${ }^{14}$ found that single "acute" sera gave positive results in 17 out of 45 patients with various confirmed viral infections. They also suggested that the interferon serum assay might be used to supplement conventional tests for viral infections.

In a previous study we detected serum interferon in all 18 rabbits after subcutaneous infection with a highly virulent strain of PED virus. Sixteen animals showed an A response, two a $B$ response, and peak interferon serum titres of 9 to 243 were attained within 2-3 days. ${ }^{5}$ The present 48 -hour sera from rabbits infected simultaneously with treponemes and PED virus were therefore considered to be useful for detecting serum interferon. We expected that interferon in serum would correlate with the early phase of PED virus infection in the animals as observed in our infection experiment, but only 27 out of the 39 virus-positive sera showed an interferon titre of $>9$.

Several factors may have contributed to this discrepancy. The interferon assay was carried out on single serum samples from rabbits of various breeds and possibly these rabbits differed in their ability to produce interferon. The rabbits had received a double infection with treponemes and PED virus, and the sera had been shipped to us under less than adequate conditions for preserving their viral inhibitory effect. The correlation between interferon production and severity of disease in comparable rabbits also suggests that the virulence of the isolates was of some importance in the interferon response and the above discrepancy. This is supported by the 
results of an infection experiment with an isolate from laboratory No 12 (unpublished observation), in which four rabbits infected subcutaneously gave a C or $\mathrm{D}$ clinical response and maximum interferon titres of $9,3,3$, and $<3$ on the second or third day. This finding corresponds to the findings with sera from laboratories Nos 12 and 5 b.

Clearly, an interferon titre of 3 or transient fever after serum inoculation does not necessarily indicate that the rabbit serum contained PED virus. Two of the 16 postinoculation sera from the virus-negative group showed a rise in titre from $<3$ to 3 and one serum produced transient fever at inoculation. Similarly, four of the 55 preinoculation sera resulted in transient fever. The interpretation of these findings remains speculative, but non-viral inducers or micro-organisms other than PED virus cannot be excluded. Nevertheless, serum interferon titres of $\geqslant 9$ always indicated the presence of PED virus and, as seen from table II, all laboratories in which PED virus was present had one or more sera with titres of $\geqslant 9$ in contrast to laboratories from whose rabbit sera no PED virus was isolated.

In this study the serum interferon assay provided useful presumptive evidence that PED virus was a contaminant of rabbit-passaged treponemal suspensions. At present PED virus can only be diagnosed by a time-consuming test in rabbits. The interferon assay may therefore be a simple method for detecting possible viral contamination of $T$ pallidum propagated in rabbits.

\section{References}

1. Gudjónsson H, Newman B, Turner TB. Demonstration of a virus-like agent contaminating material containing the Stockholm substrain of the Nichols pathogenic Treponema pallidum. Br J Vener Dis 1970; 46:435-40.

2. Menke HE, van der Heiden CA, Kruizinga W, Kruijt BC, Osterhaus ADME. Intercurrent death of rabbits after inoculation with Treponema pallidum in the Netherlands. 7th ICLAS Symposium, Utrecht 1979, Stuttgart: Gustav Fischer Verlag, 1980:263-8.

3. Fennestad KL, Bruun L, Wed $\emptyset$ E. Pleural effusion disease agent as passenger of Treponema pallidum suspensions from $\mathbb{Q}$ rabbits. Survey of laboratories. Br J Vener Dis 1980; 56: 198-203.

4. Gudjónsson H, Newman B, Turner TB. Screening out a viruslike agent from the testicular suspension of the Nichols pathogenic $T$ pallidum. With observations on certain characteristics of the agent. Br J Vener Dis 1972;48:102-7.

5. Fennestad KL, Haahr S, Bruun L. Pleural effusion disease in $\mathcal{O}$ rabbits. Interferon in body fluids and tissues after experimental $(N)$ infection. Acta Pathol Microbiol Scand (B) 1979;87:311-5.

6. Small JD, Aurelian L, Squire RA, et al. Rabbit cardio- O myopathy. Associated with a virus antigenically related to human Coronavirus strain 229E. Am J Pathol 1979; 95:709-29. का

7. Vaisman A, Paris-Hamelin A, Catalan F, Dunoyer F. Entretien $\vec{A}$ au laboratoire des souches de tréponèmes pathogènes. $\vec{\omega}$ Precautions à prendre. La Prophylaxie Sanitaire et Morale $\mathrm{O}$ 1973; 45:71-3.

9. Valle MJ, Jordan GV, Haahr S, Merigan TC. Characteristics of immune interferon produced by human lymphocyte cultures $c$ compared to other human interferons. J Immunol 1975; 115:230-3.

10. Fennestad KL, Skovgaard Jensen H-J, Møller S, Bentzon MW. Pleural effusion disease in rabbits. Clinical and postmortem $\bullet$ observations. Acta Pathol Microbiol Scand (B) 1975;83:541-8. O

11. Wheelock EF, Sibley WA. Interferon in human serum during clinical viral infections. Lancet 1964; ii:382-5.

12. Petralli JK, Merigan TC, Wilbur JR. Circulating interferon after measles vaccination. $N$ Engl J Med 1965;273:198-201.

13. Jao RL, Wheelock EF, Jackson GG. Production of interferon in volunteers infected with Asian influenza. J Infect Dis 1970; 121:419-26.

14. Matthews THJ, Lawrence MK. Serum interferon assay as a possible test for virus infections of man. Arch Virol 1979; 59:35-8. 